\title{
LOBINGER, Fritz Dom. Altar vazio. As comunidades podem pedir ordenação de ministros próprios? Aparecida: Editora Santuário, 2010. 140p.
}

João Batista Libanio*

Agita-se muito o problema da ordenação de homens casados - viri probati. Em diversos setores da Igreja latina, propugna-se a introdução dessa prática, conhecida no rito oriental, agora no rito latino. Roma tem resistido a tais demandas por razões disciplinares e pastorais, já que dogmaticamente nada haveria contra. Nos primeiros séculos a Igreja primitiva a conheceu, começando pelos próprios apóstolos.

A proposta, porém, deste livro vai noutra direção. É bem original e consistente de tal modo que ele espera, no momento em que as condições se derem, Roma a aceitaria.

O autor, Lobinger, é um bispo alemão (*1929), emérito da diocese de Aliwal na África do Sul, onde exerceu o ministério episcopal de 1988 a 2004. Hoje se dedica a correr o mundo lançando essa proposta dos ministros ordenados.

A presente obra conjuga diversas qualidades fundamentais. Consegue expor com clareza um projeto de Igreja em que haja ministros ordenados. Ele o faz de maneira simples, concisa e ilustrada. Para cada capítulo há uma figura bem clara e expressiva, em torno da qual se escreve um texto elucidativo, terminando com perguntas para reflexão pessoal, grupal e comunitária. A estrutura didática do livro favorece a conscientização e o esclarecimento da proposta pastoral, permitindo aos que a discutem constatar a sua viabilidade como processo e depois como concretização.

De que não se trata? Da simples proposta de ordenar homens casados para suprir a carência de padres. Expõe os inconvenientes desse caminho e as razões sensatas de Roma o rejeitar como medida universal para toda a Igreja. Em seu lugar, insiste na formação do espírito comunitário de maneira que os fieis se entendam como uma comunidade que se sente responsável de prover para si os diversos ministérios. Muitas já dispõem de vários

\footnotetext{
* Doutor em Teologia (Gregoria-Roma) e professor da FAJE (Faculdade Jesuíta de Filosofia e Teologia). País de origem: Brasil. E-mail: secteologia@faculdadejesuita.edu.br
} 
deles. Agora consistiria em ampliar a diversidade de ministérios e carismas, escolhendo alguns dos fieis para serem ministros ordenados.

Insiste que não se trata de ordenar indivíduos, mas de ordenar uma equipe que assume o ministério ordenado. As pessoas permanecem como membros da comunidade sem nenhuma separação e distinção externa. Elas presidem as eucaristias, nunca isoladamente, mas em equipe, por turno, quando as comunidades requerem.

A intuição fundamental e original consiste em que se pensa tal ministério como serviço à comunidade e não como ordenação de indivíduos, constituídos sagrados pelo fato de serem ordenados. E o sacerdote celibatário, de tempo integral, assumiria a função principal de ser formador desses ministros. Eles pertencem normalmente à comunidade, continuando a vida de família e profissional, tal como acontece com tantos outros ministérios já existentes: exéquias, da eucaristia, da crisma, da catequese, de curso de noivos. No interior deles, haveria os ministros ordenados que não se distinguiriam externamente dos outros, mas simplesmente pela diferença do ministério exercido. Aliás, acontece com todos os outros.

Vale a pena refletir sobre tal proposta e a metodologia de preparação da comunidade para tal ministério. Não viria como decisão para a Igreja universal, mas sim as comunidades, à medida que estivessem maduras e com leigos preparados, levariam a Roma o pedido da implementação de tal ministério. Nenhuma Igreja particular, local ou nacional, se sentiria obrigada a assumi-lo. E isso iria acontecendo onde e quando as comunidades quisessem, se sentissem aptas e preparadas.

$\mathrm{O}$ autor trabalha os argumentos a favor da proposta. Antecipa as objeções e dificuldades que despontam, procurando discutir com o leitor e o grupo de reflexão as soluções. Bispos, padres ou leigos engajados nas comunidades, que se sintonizassem com a proposta a fim de criar outro tipo de comunidade eclesial, teriam aí subsídios concretos, claros e bem estruturados. A proposta vai além da simples resposta à carência de sacerdotes, mas a um novo tipo de comunidade eclesial de base, em que os fieis assumissem clara e expressamente a responsabilidade de conduzi-la. Reinterpreta a função do atual padre na linha da finalidade da formação da comunidade e não tanto na do exercício absorvente da sacramentalização. Vale a pena conferir! 